Teachers' instructional task performance and quality assurance of students' learning outcomes in Nigerian secondary schools

Ayeni, Adeolu Joshua $\$
Ondo State Quality Education Assurance Agency, Akure, Nigeria (ayeniadeolu@yahoo.com)

Afolabi, Eyitayo Rufus Ifedayo

Obafemi Awolowo University, Ife-ife, Nigeria (eriafolabi@oauife.edu.ng)

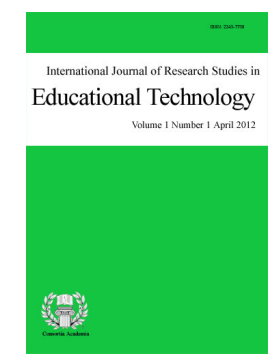

ISSN: $2243-7738$ Online ISSN: 2243-7746

OPEN ACCESS

\title{
Abstract
}

This study examines the relationship between teachers' performance of instructional tasks and students' academic performance in the teaching-learning process of secondary schools. The study employed the descriptive survey design paradigm. Respondents consist of 60 principals, 540 teachers and 1800 students that were randomly selected using the multi-stage sampling technique from a pool of 599 public secondary schools (now re-articulated into 301) in Ondo State, South-West, Nigeria. Research instruments tagged, “Teachers' Instructional Task Performance Rating Scale" (TITPRS), "Students' Rating Scale", Interview Guide for Principals and Teachers' Focus Group Discussion Guide (FGD) were used for data collection. The hypothesis was tested for significance at $p<0.05$ probability level of significance, using the Pearson product moment correlation statistics. The study reveals that the major instructional tasks performed by the teachers are the preparation of lesson notes, wrting of scheme of work, and periodic assessment of students' learning. While the tasks that are least performed by teachers are research into teaching and learning activities, improvisation and usage of instructional materials, marking of exercises/assignments, and regular feedback to students. Furthermore, the results shows that the majority of students $(62.2 \%)$ perceived their teachers' performance of instructional task as very effective. Results also shows that the relationship between teachers' instructional tasks and students' academic performance is significant $(r=0.828$ at $p<0.05)$ with the teachers' tasks (Mean $=42.17)$ and students' performance $($ Mean $=2.73)$. This implies that many schools are still striving to achieve quality assurance in students' academic performance. The study concluded that improvement in the tasks of instructional resource inputs, curriculum delivery, and students' learning require effective and goal-oriented interrelationship between the school and other stakeholders in education.

Keywords: secondary school; quality assurance; teacher's quality; learning resources; learning space; instructional performance; school principals; student learning outcome 


\section{Teachers' instructional task performance and quality assurance of students' learning outcomes in Nigerian secondary schools}

\section{Introduction}

Quality assurance is the set of activities that an organization undertakes to ensure that a product or service will satisfy given requirement for quality. This implies that standards are specified and reached consistently for a product or service. In addition, the goals of quality assurance are focused on the anticipation and avoidance of faults or mistakes. This process basically involves setting attainable standards, organizing work and monitoring performance so that objectives are achieved as well as ensuring the documentation of procedures required, communicating them to all concerned in order to review the attainment of standards.

Harvey (1999) views quality assurance as the process of ensuring effective resource input, control, refining the process and raising the standards of output in order to meet the set goals and satisfy public accountability. In the context of qualitative education delivery, Ayeni (2010) described quality assurance in education as the systematic management, monitoring and evaluation of performance of school administrators, teachers and students against educational goals to ensure consistent documentation, review and decision towards quality improvement in institutional management, and teaching and learning processes for the achievement of set standards in schools. This conception raises the issue of promoting a value system in the institutional management which emphasizes production of quality learners' outcomes in the teaching-learning process.

A critical look at the definitions show that quality assurance is evidence-based and as such depends on efficient and effective management, resource utilization, curriculum delivery, monitoring, evaluation and reviews of the resource inputs and transformation process (teaching and learning) to produce quality outputs (students) that meet set standards and expectations of the larger society. The societal quest for quality teaching which is a vital aspect of quality assurance is imperative because of the emergence of new information technologies, the evolution of the global digital economy and the global competition for technically skilled workers creates a national urgency to improve the educational standard in secondary schools. This is an issue of preeminent national importance that must serve as guide post to principals and teachers, so as to effectively prepare all students to be contributing citizens and productive workers in the $21^{\text {st }}$ century (CEO Forum Policy Paper, 2001).

The increasing demand for high quality education by the stakeholders in education and the society at large has posed serious challenge to principals, teachers and students in the school setting. The school should therefore strive hard to achieve educational goals (ideal vision) in the task of training the students since effective schools are found to be those which have high expectations of all students and think that every child has potentials to achieve. It is this belief that should inform the school principal, most of the time, of the need to be goal-oriented and optimally maximize human and material resources, and be more proactive in monitoring, evaluating and coordinating teachers for effective task performance that will lead to the achievement of the set educational goals (Ogundele, 2002).

\subsection{Students' learning outcomes and quality assurance}

Students' learning outcome is the quality of knowledge, skills, attitudes and values acquired in the cognitive, affective and psychomotor domains of educational objectives for necessary self-confidence, self-reliance, effective citizenship, responsiveness to opportunities and challenges of life (Mishra, 2008). The quality of students' learning outcomes is undoubtedly dependent on teachers' knowledge, skills and competencies in instructional task performance. 
Teachers' instructional task performance and quality assurance of students' learning outcomes

The attainment of quality assurance by students is, however, a challenging phenomenon in developed, developing and less developed countries. For instance, Coates McBride and Kristonis (2008) reporting on America situation revealed that the international assessments report released in 1983 described American education as $\boldsymbol{A}$ Nation at Risk since American children seriously lag behind international students of equal age and grade in academics. This attracted attention of parents, educators and elected officials. Consequently, both Presidents Clinton and Bush have made the attainment of high national standards and assessment of students' performance, a substantive reform in the quality of education an important platform of their political agenda. States and ultimately local school districts have from that time grappled with ways of improving their educational systems.

Also, in a study by Zobaida (2008) on Bangladesh, it was found that most of the students were not serious about their studies because of their economic crisis and lack of time. They have to earn side by side with their studies, so the subject matter of the courses seem to them hard. This situation has perhaps been responsible for students' low academic performance. Consequently, emphasis was placed on students' supportive service and systematic monitoring and evaluation of students' participation in schools' activities with increased interaction between the students and teachers which serves as motivational impetus and stimulating learning environment for sustainable improvement in students' learning outcomes.

The Federal Ministry of Education (2006) reporting on Nigeria, revealed that the academic performance of students in the Senior School Certificate Examinations conducted between 2000 and 2006 was below fifty percent (50\%). The performance of Nigerian Secondary school students in external examinations showed $98 \%$ failure rate in the 2009 November/December Senior School Certificate Examinations conducted by the National Examination Council (NECO-SSCE); out of the total number of 234,682 candidates who sat for the examination, only 4,223 obtained credits level passes and above in five subjects including English and Mathematics (Bello-Osagie \& Olugbamila, 2009). In the 2009 May/June Senior School Certificate Examination conducted by the West African Examination Council (WASSCE), only 25.99 percent of the total number of candidates obtained credit level passes and above in five subjects including English Language and Mathematics, while in the 2010 May/June WASSCE, out of the 1,135,557 candidates that sat for the examination, only 337,071 (24.94\%) obtained five credit level passes and above in subjects that included English Language and Mathematics (Owadiae, 2010).

In the same vein, in Ondo State, students' results in the Senior School Certificate Examination conducted by the West African Examination Council (WASSCE) between 2007 and 2009 ranged from 16.7\% to $19.1 \%$ and the same in the National Examination Council (NECO-SSCE) ranged from 3.2\% to 27\%, and 35\% in 2010 (Ayeni, 2010; Quality Education Agency, 2010). Also in 2011 May/June Senior School Certificate Examinations conducted by the West African Examination Council, only 30.99\% of the 1,540,250 candidates obtained credit level passes and above in five subjects including English Language and Mathematics in the 36 States of the Federation, and the Federal Capital Territory (Owadiae, 2011). Consequently, several intervention programs (capacity building of teachers, procurement of textbooks, science equipment, construction and renovation of classrooms, provision of running grants and establishment of Quality Education Assurance Agency) are being implemented to revamp the education sector for better performance.

The declining of standard of secondary education in Nigeria poses serious challenge to principals, teachers, and students who constitute the primary focus in quality assurance system. It therefore assumes that principals the as quality assurance agents in secondary schools need to ensure qualitative service delivery by continuously monitoring performances of teachers as well as students against educational objectives to ensure best practices in inputs and through-put which lead to quality outputs that will meet the yearnings and aspirations of the larger society (i.e. national and international acceptable standard). The findings by Federal Ministry of Education (2006), Coates-McBride and Kristonis (2008), Zobaida (2008), Bello-Osagie and Olugbamila (2009), and Quality Education Assurance Agency (2010) have made it crystal clear that students' learning outcome is below quality assurance standard in secondary schools. 


\subsection{Teachers' quality and instructional task performance}

Instructional tasks are statutory curricula functions that are performed by the teachers to enable learners achieve the set educational goals in schools. This ultimately depends on the avowed commitment of principals and teachers to make judicious and adequate use of both human and material resources to ensure quality assurance in the teaching-learning process. Teacher quality is the ability of the teacher to demonstrate sound professional attributes like scholarship through adequate training and it is pivotal to successful teaching, students' learning outcomes and attainment of quality education in secondary schools. Teachers' quality is manifested in their knowledge of the subject-matter, skills and competences in the teaching and learning processes, which leads to the accomplishment of the stated educational goals. This means that the real teacher must possess the qualities for effective teaching and pleasant learning within the school setting. He must know what he is to teach, how he is to teach, and whom he is to teach. The purpose is to deliver the curriculum efficiently, so as to achieve the set goals and standards in schools (Koleoso, 2002; Makinde \& Alao, 1992).

The teacher's role is crucial to effective and efficient learning, the teacher is expected to provide essential inputs like adequate planning of lesson notes, effective delivery of lessons, proper monitoring and evaluation of students' performance, providing regular feed-back on students' performance, improvisation of instructional materials, adequate keeping of records and appropriate discipline of students to produce and enhance expected learning achievement in secondary schools (Ayeni, 2010). The purpose of any teacher in the classroom is to help learners learn, inquire, solve problems, and cope with their own emotional needs and tensions. The teacher promotes quality education from the domain of teaching and learning through creative idea, participation and cooperative learning, research, analysis and critical thinking, problem solving, innovation and encouragement of creative and divergent thinking. These lead to the proper development of knowledge, skills, attitude, values that enable students to function effectively and live as responsible citizens and also makes useful contribution to the society.

In order to ensure effective teaching and learning process, Withall (1975) opined that, teachers must create a psychologically non-threatening, non-inhibiting climate but at the same time a cognitively challenging situation to help the learners to predict the consequences of certain courses of action and to identify, if need be, alternative activities. This all adds up to the need for the teacher to constantly challenge the learners intellectually without undermining their sense of individuals' worth or integrity. Aside the knowledge of lesson plans, record-keeping, use of audio-visual aids and standardized testing, it is also imperative for the teacher to possess a good measure of self-understanding, psychological awareness and insight so as to be able to demonstrate expert quality in the performance of instructional tasks (Bottery, 2008).

The quality of students' learning outcomes is directly dependent on the quality of teachers as demonstrated in their knowledge of the subject matter and capacities to effectively carry out instructional tasks with the ultimate aim of facilitating the learning of diverse students and raises achievement for all learners to meet the specified standards and satisfaction of the larger society (Middlehurst \& Gordon, 1995). The teachers' quality and instructional task performance are germane to the achievement of any well-developed quality assurance system in secondary schools. Ameen (2007) highlighted the areas to be focused by teachers to ensure quality as follows:

$>$ Formulating aims and goals of program in a thoughtful manner

> Regular curriculum implementation and revisions

$>$ Teaching methodology and assessment methods

$>\quad$ Staff development

$>$ ICT education, modern teaching aids and physical environment 
$>$ Internal quality assurance and,

$>$ Cooperation at national and international level

The teachers' professional tasks and effectiveness indicators/traits highlighted by Ameen (2007), Bottery (2008), Koleoso (2002), Makinde and Alao (1992), Middlehurst and Gordon (1995), and Withall (1975) include: understanding of educational goals, continuous learning, professional competence, sound knowledge of the subject matter, proper planning of lessons, regular curriculum implementation, optimization of instructional resources, class management, assessment of students' learning outcomes, expectations of success for all students, record-keeping, self-understanding and control, psychological insight and collegiality. These are considered relevant to the development of instrument for the present study, which is intended to examine teachers' instructional tasks in the context of quality assurance in secondary schools.

The study is based on the systemic model of education quality assurance which recognizes the school as an open system that receives inputs from the society for institutional process and output (intended outcome). The sub-units within the school are interdependent and connected through a network of interrelationships geared towards the realization of the set goals. It is the business of the school to admit students as input from the society, expose them to curricula through efficient teaching-learning process, utilization of available resources, materials and adequate instructional supervision. This process enables the individuals to develop cognitive, affective and psychomotor powers for the discovery of their inner lying potential abilities for higher education, technical and vocational training, while in the long run, the students come out as outputs in form of educated persons (intended outputs) ready to enter the labor market for self-reliant and community development. This underscores the reason for making education the child centered.

\subsection{Statement of the problem}

There have been steady decline in teachers' instructional task performance and students' academic performance which depicts non-realization of quality assurance in secondary schools (Adeniji, 2002). This has been attributed to gaps in teachers' competence, curriculum instruction, learning facilities and resources, funding and institutional management. Findings from literature (Ayeni \& Akinola, 2008; Ipaye, 2002; Ogunu, 2001; Okebukola, 1996; Zobaida, 2008) revealed that quality assurance in education is being affected by many problems. The identified gaps and challenges include the following:

$>\quad$ Inadequate provision of instructional materials and facilities for the teaching-learning activities;

$>\quad$ Inadequate planning and delivery of lessons by teachers;

$>\quad$ Lack of proper monitoring and evaluation of students' learning; and

$>\quad$ Inadequate provision of training facilities to develop teachers for professional growth and increased productivity.

A consideration of the above shows that there is a greater challenge ahead of principals and teachers partly because of existing gaps and inadequacies in their instructional duties. Thus, the purpose of this study was to examine teachers' instructional task performance in meeting the challenges of quality assurance which has been eluding secondary school system in Ondo state which is the only state with a full-fledged autonomous Quality Assurance Agency in South-West, Nigeria.

\subsection{Research questions}

The following research questions were raised to guide the study:

1. What instructional tasks are performed by teachers in secondary schools? 
Ayeni, A. J. \& Afolabi, E. R. I.

2. How do students perceive teachers' instructional task in secondary schools?

3. What are the effects of teachers' instructional task performance on students' academic performance in secondary schools?

\subsection{Objectives of the study}

The specific objectives of this study are to:

1. Examine teachers' instructional tasks in secondary schools; and

2. Determine the relationship between teachers' instructional task performance and students' academic performance.

\subsection{Hypothesis}

The hypothesis formulated to guide this research study is that there is no significant relationship between teacher's instructional task performance and students' academic performance.

\section{Methodology}

The study employed the descriptive survey design. With this design, both quantitative and qualitative methods which involve systematic and objective collection and analysis of data were adopted to elicit responses from the participants in order to find solutions to the problems identified. The target population comprised principals, teachers and students in secondary schools in Ondo state, Nigeria. The respondents consisted of 60 principals, 540 teachers and 1,800 students randomly selected from 60 secondary schools using multi-stage sampling technique. The 60 secondary schools were selected from the existing 599 public secondary schools (now re-articulated into 301) using stratified random sampling method from five (5) Local Government Areas (LGAs) that were randomly selected from the existing five educational zones in Ondo Sate. The instruments used for data collection were self-developed questionnaires tagged: "Teachers' Instructional Task Performance Rating Scale" (TITPRS), "Students' Rating Scale" (SRS), Interview Guide for Principals and Teachers' Focus Group Discussion Guide (FGD) were used for data collection. Three research questions were formulated and the hypothesis was tested for significance at $p<0.05$ probability level of significance.

The questionnaire contained two sections (A and B); section A of the TITPRS dealt with demographic and general information. The section B of the TITPRS instrument contained a total of 12 items developed by the researcher for the principals to rate the quality of teachers on the following variables: planning and delivery of lessons, instructional material, learning resources, class management, record keeping, students' academic assessment, feedback and reviews of academic programs while section $\mathrm{C}$ of the TITPRS contained 6 items constructed for the teachers to rate students' academic performance. The section A of the SRS instrument elicited information on gender and class while Section B of the instrument contained a total of 20 items constructed for the students to rate teachers' instructional task performance in the areas of delivery of lessons, evaluation of learning outcomes, classroom management and feedback. The research instrument utilized a 5-point Likert scale questionnaire of Highly Agree, Agree, Fairly Agree, Disagree and Highly Disagree. The scale values allocated were 5, 4, 3, 2 and 1 respectively. In addition, the study made use of interview guide to collect information from principals and teachers on variables such as the nature of teachers' tasks, classroom management, instructional materials, learning resources, learning spaces, capacity building, students' learning outcome, instructional feed-back and reviews, and challenges of instructional practices. The interview was limited to three educational zones randomly selected from the five educational zones in the state. From each zone, one secondary school was randomly selected.

The instruments were validated using both content and construct validity. Each of the instruments was scrutinized by experts in Educational Administration, Test and Measurement, and Educational Technology in the 
Faculty of Education, Obafemi Awolowo University, Ile-Ife. Their suggestions were adhered to strictly and thus leading to the modification of relevant items. Ultimately, the instruments were adjudged to be suitable in measuring the constructs. Copies of the questionnaire were administered on the principals, teachers and students in their respective schools. One research assistant was employed and trained to help the researcher in the administration of questionnaire. Data collected were analyzed using percentages, mean scores and Pearson Product Moment Correlation analysis at 0.05 level of significance; using Statistical Package for Social Sciences (SPSS) version 16.0.

\section{Results}

The results of data analysis were presented in the order of the research questions while the discussions of findings were carried out in order to adequately capture the interrelatedness of the variables of the study as they affect teachers' instructional performance and students' learning outcomes. The results presented in table 1 showed that teachers carried out instructional tasks such as delivery of lessons [82\%], evaluation of learning outcomes [73\%], classroom management [74\%] and feedback on learning outcomes [75.3\%], Furthermore, students' perception of effectiveness of teachers' instructional task performance revealed the overall percentage-points of very effective [76\%], fairly effective [14\%] and non-effective [10\%]. This implies that quality assurance practice is embraced to a reasonable level in secondary schools. This is a good development that will serve as catalyst for good academic performance of students in secondary schools.

Table 1

Students' perception of effectiveness of teachers' instructional task performance $(N=1,776)$

\begin{tabular}{|c|c|c|c|c|c|c|c|}
\hline \multirow{2}{*}{ Teachers' tasks } & \multicolumn{2}{|c|}{ Very effective } & \multicolumn{2}{|c|}{ Fairly effective } & \multicolumn{2}{|c|}{ Non-effective } & \multirow{2}{*}{$\begin{array}{l}\text { Mean } \\
\text { score }\end{array}$} \\
\hline & Frequency & $\%$ & Frequency & $\%$ & Frequency & $\%$ & \\
\hline Delivery of lessons & 1451 & 82.0 & 201 & 11.0 & 124 & 7.0 & 2.75 \\
\hline $\begin{array}{l}\text { Evaluation of learning } \\
\text { outcomes }\end{array}$ & 1261 & 73.0 & 305 & 18.0 & 156 & 9.0 & 2.64 \\
\hline Classroom management & 1284 & 74.0 & 232 & 13.3 & 220 & 12.7 & 2.61 \\
\hline $\begin{array}{l}\text { Feedback on learning } \\
\text { outcomes }\end{array}$ & 1309 & 75.3 & 239 & 13.7 & 191 & 11.0 & 2.64 \\
\hline Total & 5305 & 76.0 & 977 & 14.0 & 691 & 10.0 & \\
\hline Cumulative Mean & & & & & & & 2.66 \\
\hline
\end{tabular}

The result presented in table 2 showed that the $\mathrm{r}$-value of 0.828 at $p<0.05$ is significant. The null hypothesis (Ho) of no significant is rejected while the alternative hypothesis (Ha) is accepted. This shows there is significant relationship between teachers' instructional task performance and students' academic performance. There is a high mean score of 42.17 recorded on teachers' instructional task performance, which implies that teachers accorded the desired attention to teaching and learning processes. By implication, it is clear that teachers occupy centre stage in the teaching and learning processes; consequently, students' academic performance is dependent greatly on teachers' content knowledge, pedagogical skills and competence. However, a mean score of 2.73 was recorded on students' academic performance which implied that the percentage of students that achieved quality assurance standard in the SSCE was below average.

\section{Discussions}

\subsection{What instructional tasks are performed by teachers in secondary schools?}

The rating of teachers' instructional performance by principals in the instrument yielded a mean of Mean = 3.89, items $2($ Mean = 4.42), $3($ Mean = 4.42), $9($ Mean = 4.30), $1($ Mean = 4.22), and $11($ Mean = 4.02) had the 
Ayeni, A. J. \& Afolabi, E. R. I.

highest rating while items 12 (Mean $=2.80), 5($ Mean $=3.12), 8($ Mean $=3.13)$ and $7($ Mean $=3.47)$ had the lowest ratings. Thus, it would be deduced from the ratings that the major instructional tasks performed by the teachers were: preparation of meaningful and adequate lesson notes; checking and marking of lesson notes; writing of scheme of work; periodic assessment of students' learning outcomes; supervision and invigilation of examinations. While the tasks that were least performed by teachers were: research into teaching and learning activities; improvisation and usage of instructional materials; checking, marking and regular feedback to students on their classroom exercises/assignments; stimulating students to have required textbooks and other learning materials.

The findings of the investigation, during the Focused Group Discussion (FGD) with teachers, corroborated the results of the analysis. The teachers interviewed were well informed about their instructional tasks in the school system. However, some heads of department said that about $10 \%$ of teachers were still writing skeletal lesson notes and a relatively low number of teachers engaged in research to improve curriculum delivery. This will no doubt have adverse effect on the quality of curriculum delivery. Furthermore, some teachers said that their work was being hampered by poor condition of infrastructure, lack of necessary equipment for conveniences and acute shortage of instructional materials and relevant textbooks, and excessive workload, especially in English and Mathematic in which teachers were allocated 22 to 26 periods per week in most secondary schools. This had hindered teachers from giving regular essays, comprehensions and class exercise to students.

Table 2

Relationships between teachers' instructional task performance and students' academic performance

\begin{tabular}{lccccc}
\hline \multicolumn{1}{c}{ Items } & $n$ & Mean & $S D$ & $r$ & $p$ \\
\hline $\begin{array}{l}\text { Teachers' instructional task } \\
\text { performance }\end{array}$ & 60 & 42.17 & 5.87 & 0.828 & $<0.05$ \\
$\begin{array}{l}\text { Students' academic } \\
\text { performance }\end{array}$ & 534 & 2.73 & 0.94 & & \\
\hline
\end{tabular}

\subsection{How do students perceive teachers' instructional task in secondary schools?}

The evidence from the data analysis in table 1 showed that the mean score of 2.66 was obtained in the students' perception on teachers' instructional task performance. This indicated that a relatively high number of teachers accorded desired attention to teaching and learning. However, the mean score of 2.61 recorded in item 3 in table 1 revealed that $12.7 \%$ of the secondary schools' classrooms were poorly managed. The interview conducted with some principals revealed that the class size was congested and ranged from 60-70 students per class. This constituted hindrance to effective classroom management and supervision. Specifically, some items in table 1 indicated that $56.5 \%$ of the classrooms were un-conducive for learning while $33.9 \%$ of teachers were deficient in marking students' attendance during lessons, $26.3 \%$ did not give sufficient exercises and take-home assignments, $24.1 \%$ were lukewarm in marking class exercises, assignments and notes, $35.4 \%$ gave inadequate encouragement for group work, $22.7 \%$ were deficient in giving feedback, $23.7 \%$ did not show adequate concern for students welfare and $38.5 \%$ of teachers did not maintain adequate contact with parents concerning students' academic performance. All these shortcomings constituted gaps in the quality of teachers' instructional task performance and students' learning in secondary schools.

\subsection{Relationship between teacher's instructional task performance and students' academic performance}

The relationship between teachers' instructional tasks and students' academic performances was significant $(r=0.828$ at $p<0.05)$. The result showed that most teachers accorded the desired attention to curriculum delivery; however the mean scores of 2.73 recorded on students' academic performance indicated that the percentage of 
Teachers' instructional task performance and quality assurance of students' learning outcomes

students that achieved quality assurance standard in the external examinations was below average, indicating that many schools were still striving to achieve quality assurance standard in students' academic performance. The interview conducted with some teachers revealed that most of the students were lazy and could hardly spend 30 minutes reading, they preferred to watch film and games on television/video clips. Most of the students lack relevant textbooks and other learning materials. For instance, out of a population of 130 students in senior secondary class two in a particular school, only 13 (10\%) had recommended textbooks in English Language, Mathematics and Biology while only $2 \%$ had textbooks in Yoruba Language and Accounting, and non in other subjects while some of the parents expected the school to promote their children whenever they failed examinations. This situation portends serious danger to the education system since no meaningful learning can take place without students having relevant textbooks and other learning materials to read, study and practice.

The principals interviewed said that great attention were given to students' academic training and enhanced by organizing inter-class and inter-school debate and quiz competitions to stimulate healthy academic rivalry among students. The best students in the terminal examinations were given prizes while the photographs of the overall best students in academic in each class were put on the notice board as a mark of recognition. The level of students' academic performance ranged from $40 \%$ to $45 \%$. Out of a class of 40 students, only 5 have English textbook, 2 have Mathematics textbook and non in other subjects. The majority of parents (88\%) did not provide relevant textbooks for their children/wards.

Aside from those challenges earlier identified, the other ones affecting teachers' instructional tasks and students' learning includes many of the secondary schools lack well equipped laboratories and libraries. There were multipurpose science laboratory as against the autonomous science subject laboratory. There were no adequate fixtures, equipment and reagents in the laboratory. In most cases, science subjects were taught in abstract. Many schools were short-staffed while some teachers were overloaded and made to teach subjects outside areas of specialization since some of the teachers transferred were not replaced especially in Akoko, Okitipupa, and Owo educational zones. The affected subjects were English Language, Mathematics, Integrated Science, Physical and Health Education, Home-Economics, Fine-Art, Computer Studies, Wood Works, Metalwork, and Auto Mechanics.

\section{Conclusion}

The study concluded that the gaps in input-process-output system were challenges that principals and teachers faced in the tasks of resource inputs, instructional performance and students' learning which require effective and active goal-oriented interrelationship between the school and other stakeholders in its environment. This is a means of ensuring continuous improvement in resource inputs, transformational process and outputs since the school cannot achieve the set educational goals in isolation.

\subsection{Recommendations}

The school principals should provide constant and adequate feedback to the teachers on their instructional task performance to ensure periodic review and facilitate capacity development for further improvement in classroom management and curriculum delivery in secondary schools. The school authority should provide constant and comprehensive feedback on students' academic performance to parents in order to sensitize and encourage them to provide the required textbooks and other learning materials for their children/wards. School principals should promote healthy academic competitions such as intra and inter-class/school debate, quiz and essays among students to improve their knowledge, skills, competence and performance. Government should employ adequate number of teachers and ensure equitable distribution to all secondary schools, so as to maintain reasonable teachers' workloads and effective coverage of all subjects on the school curriculum. 


\section{References:}

Adeniji, I. A. (2002). Perception of principals and teachers of external supervisors' role in secondary schools in Ogun State. Nigerian Journal of Clinical and Counselling Psychology, 8(1), 43-56.

Ameen, K. (2007). Issues of quality assurance in LIS higher education in Pakistan. Paper presented at the World Library and Information Congress, Durban, South Africa.

Ayeni, A. J. (2010). Teachers' instructional task performance and principals' supervisory roles as correlates of quality assurance in secondary schools in Ondo State. Unpublished Doctoral dissertation. Obafemi Awolowo University, Ile-Ife, Nigeria.

Ayeni, A. J., \& Akinola, O. B. (2008). Influence of principals' leadership styles and motivation of teachers on quality assurance in secondary school: A case study of Ondo State. Ife Journal of Theory and Research in Education, 2(1-2), 162-170.

Bello-Osagie, K., \& Olugbamila, A. (2009, December 31). Events that shape education. The Nation, p. B2,

Bottery, M. (2008). Uses and abuses of quality: The need for civic version. In Strategic leadership and educational improvement (pp. 60-73). London: Sage Publication.

CEO Forum Policy Paper. (2001, March). Education technology must be included in comprehensive education legislation. CEO Forum Policy Paper, p. 1,

Coates McBride, A., \& Kritsonis, W. A. (2008). The M and M effect - Assessing the impact of merit pay on teacher motivation: National implications. National Journal for Publishing and Mentoring Doctoral Student Research, 5(1), 1-6.

Federal Ministry of Education. (2006). Operation reach all secondary schools inspection exercise. Abuja: Federal Ministry of Education Publication.

Harvey, L. (1999). An assessment of past and current approaches to quality in higher education. Australian Journal of education, 43(3), 237-255.

Ipaye, B. (2002). Teachers apathy to teaching. Journal of All Nigeria Conference of Principals of Secondary Schools, 2002, 185-198.

Koleoso, A. (2002). Planning an effective educational programme for Nigerian schools. In Educational administration for colleges of education and universities. Owerri: Tony Ben Publishers.

Makinde, O., \& Alao, K. (1992). Profile of career. Ile-Ife: Faculty of Education, Obafemi Awolowo University.

Middlehurst, R., \& Gordon, G. (1995). Leadership, quality and institution effectiveness. Higher Education Quarterly, 49(3), 267-285. <http://dx.doi.org/10.1111/j.1468-2273.1995.tb01680.x>

Mishra, R. C. (2008). Educational research and development. New Delhi: APH Publishing Corporation.

Ogundele, A. (2002). Planning an effective educational programme for Nigerian schools. In Educational administration for colleges of education and universities (pp. 47-61). Owerri: Tony Ben Publishers.

Ogunu, M. A. (2001). Problems of school inspection in Nigeria. In Nigeria Association of Educational Administration and Planning (Ed.), Current issues in educational management in Nigeria (pp. 270-281). Nigeria: NAEAP.

Okebukola, P. (1996). Meeting the challenges of secondary school administration in Nigeria. Journal of All Nigeria Conference of Principals of Secondary Schools, 2002, 159-171.

Owadiae, I. (2010, August 31). West African Senior School Certificate Examination result. The Punch, p. 39,

Owadiae, I. (2011, August 11). West African Senior School Certificate Examination result. The Nation, p. 4,

Quality Education Agency. (2010). Analysis of results of WAEC/NECO Senior Secondary School Certificate Examinations. Ondo State, Nigeria: Quality Education Agency.

Withall, J. (1975). Teachers as facilitators of learning: A rationale. Journal of Teacher Education, 26(3), 260-266. <http://dx.doi.org/10.1177/002248717502600319>

Zobaida, A. (2008). Quality assurance in secondary education programme of Bangladesh Open University: Present status and challenges [In Turkish]. Journal of Distance Education, 9(2), 35-43. 